\title{
Determination of Tissue Distribution of Alisol G, a CB1R Antagonist, in Rats by Ultra-High-Performance Liquid Chromatography-Tandem Mass Spectrometry
}

\author{
Chen-Yu Gao ${ }^{1, *}$ Jian-Qiang $\mathrm{Xi}^{1, *}$ Ding-Zhong Song ${ }^{1}$ jie Yuan ${ }^{1}$ Wu-Si Hao ${ }^{1}$ Zhong-Bao Cui ${ }^{1}$ \\ Zhi-Hong Cheng ${ }^{1, *}$ \\ ${ }^{1}$ Natural Products Pharm. Lab, National Pharmaceutical Engineering \\ Research Center, China State Institute of Pharmaceutical Industry, \\ Address for correspondence Zhi-Hong Cheng, PhD, National \\ Zhangjiang Hi-Tech Park, Pudong New District, Shanghai, People's \\ Republic of China \\ Pharmaceutical Engineering Research Center, China State Institute of \\ Pharmaceutical Industry, 1111 Halei Road, Zhangjiang Hi-Tech Park, \\ Pudong New District, Shanghai 201203, People's Republic of China \\ (e-mail: zhcheng324@126.com). \\ Pharmaceut Fronts 2020;2:e179-e187.
}

\begin{abstract}
Keywords

- Alisol G

- UHPLC-MS/MS

- tissue distribution

- blood-brain barrier

Peripheral CB1R blockers without crossing the blood-brain barrier (BBB) have demonstrated therapeutic benefits in metabolic syndromes, including obesity. Among them is Alisol G, a tetracyclic triterpene from Alismatis rhizoma (zexie), which can effectively reduce the weight of obese mice. Results from CP55940-induced [35s]GTP $S$ cannabinoid-type 1 receptor (CB1R) binding assay show an $\mathrm{IC}_{50}$ of $34.8 \mu \mathrm{mol} / \mathrm{L}$ for Alisol $\mathrm{G}$, implicating its role as a CB1R antagonist. The purpose of our study is to assess whether Alisol G could serve as a peripheral CB1R antagonist for obesity treatment. In this study, we build a simple, reliable, and sensitive method to detect the concentration of Alisol $G$ in rat tissue by ultra-highperformance liquid chromatography-tandem mass spectrometry (UHPLC-MS/MS). The results showed that Alisol $\mathrm{G}$ was mainly distributed in intestinal midgut, mucosa and small intestine, with little brain exposure. We suggested that intestine may be the main acting sites of Alisol G. Through comparison of brain and blood concentrations of Alisol G, our data showed that Alisol $G$ cannot penetrate the BBB easily. In conclusion, Alisol G may represent a peripheral CB1R antagonist for the further treatment of obesity.
\end{abstract}

\section{Introduction}

Alismatis rhizoma (zexie) is documented in the oldest materia medica book, "Shennong's Classic of Materia Medica," and has been used as a Chinese herbal medicine for hypolipemic, anti-inflammation, and antiatherosclerotic benefits for thousands of years. Alisol G is a triterpenoid from Alismatis rhizoma. Our previous studies showed that Alisol G significantly inhibited body weight gain, while improved glucose and lipid metabolism of obese mice. ${ }^{1}$ Evidence suggested that the blockade of the cannabinoid-type 1 receptor (CB1R) is one of the promising strategies for the treatment of

Both authors contributed equally to this work.

received

December 9, 2020

accepted

January 12, 2021

published online

March 19, 2021 obesity. ${ }^{2}$ An $\mathrm{IC}_{50}$ value of Alisol G antagonizing CB1R was $34.8 \mu \mathrm{mol} / \mathrm{L}$ that measured by the $\left[35_{S}\right]$ GTP $S$ binding test, implying the antagonizing effect of Alisol G on CB1R. Alisol G has a significant effect on weight loss and hypoglycemic effects in obese mice induced by high-fat diet ${ }^{1}$; however, whether Alisol $\mathrm{G}$ serves as a peripheral CB1R antagonist to exert antiobesity effect remains largely unknown.

CB1R is mainly distributed in the central neural system, such as brain tissue, and is also expressed in peripheral tissues such as intestine, fat, and liver. Han et al suggested that inhibiting CB1R in the central neural system suppresses appetite; however, a long-term antagonism of central CB1R can cause depression, headache, nausea, and other side effects. $^{3}$ For example, rimonabant is a brain-acting CB1R

(c) 2021. The Author(s).

This is an open access article published by Thieme under the terms of the Creative Commons Attribution License, permitting unrestricted use, distribution, and reproduction so long as the original work is properly cited. (https://creativecommons.org/licenses/by/4.0/)

Georg Thieme Verlag KG, Rüdigerstraße 14, 70469 Stuttgart, Germany 
antagonist that has a significant effect in weight reduction. It was developed by Sanofi and introduced to the market in 2006, only to be withdrawn from the market because of the side effect such as suicide tendency, headache, and nausea after long-term use, demonstrating that peripherally restricted CB1R antagonists might be pursued instead. ${ }^{2}$ Inhibition of peripheral CB1R demonstrated an antiobesity effect mainly through slowing bowel movements, inhibiting liver lipid production, promoting the conversion of white fat to brown fat, and improving energy metabolism. ${ }^{3}$ Thus, exploring peripheral CB1R blockers without penetrating the barriers between blood and brain has become a research focus in obesity treatment. 4,5

There are three major barriers between blood and brain, which are divided into blood-brain barrier (BBB), bloodcerebrospinal fluid barrier (BCSFB), and cerebrospinal fluidbrain barrier (CSF-brain barrier). ${ }^{6}$ Our previous study investigated the concentration of Alisol G in blood and CSF. ${ }^{1}$ In this article, we measured the concentration of Alisol G in peripheral and brain tissues, and compared the distribution of Alisol $G$ in peripheral tissues and central nervous system of rats. Herein, we established a simple, fast, and sensitive ultra-high-performance liquid chromatography-tandem mass spectrometry (UHPLC-MS/MS) method to assess the content of Alisol $\mathrm{G}$ in different tissues. Our data suggested that Alisol G may serve as a peripheral CB1R antagonist that probably exerts its effect in the intestines. To our knowledge, this is the first time that a tissue distribution pharmacokinetic study of Alisol G has been reported.

\section{Materials and Methods}

\section{Chemicals and Reagents}

Alisol $\mathrm{G}$ was extracted and purified to a purity $>98 \%$ at National Pharmaceutical Engineering Research Center, China State Institute of Pharmaceutical Industry, Shanghai, China. Rimonabant was purchased from Shanghai Yuanye Bio-Technology Co., Ltd. Methanol, acetonitrile, and tertbutyl methyl ether (HPLC grade) were obtained from Merck (Germany). Acetic acid (HPLC grade) was obtained from Aladdin Reagent. CMC-Na (pharmaceutical grade) was obtained from Shanghai Chineway Pharmaceutical Tech Co., Ltd. All other reagents were of analytical-grade purity.

\section{Animals}

Twenty-five Sprague Dawley (SD) male rats (180-200 g) were purchased from Shanghai Shiple-Bikey Laboratory Animal Co., Ltd. Before the experiment, the animals were housed for 7 days on a 12-hour light/dark cycle at room temperature (r.t.) of $22 \pm 2^{\circ} \mathrm{C}$ and humidity of $55 \pm 5 \%$. All animals were fasted for 12 hours before experiments and for another 2 hours after oral drug administration. Water was freely available at all times.

\section{Instrumentation and Conditions}

The UHPLC-MS/MS analysis was performed using an ACQUITY UPLC I-Class system (Waters, United States) coupled with a XEVO TQMS tandem quadrupole mass spectrometer (Waters, United States) with an electrospray ionization (ESI) source in multiple reaction monitoring (MRM) mode. Data acquisition and quantification were conducted with MassLynx 4.1 version data software (Waters, United States). Chromatography separation process was performed on an ACQUIT BEH C18 $(100 \mathrm{~mm} \times 2.1 \mathrm{~mm}, 1.7 \mu \mathrm{m}$; Waters, United States) at $35^{\circ} \mathrm{C}$. The flow rate was $0.2 \mathrm{~mL} / \mathrm{min}$. The mobile phase was methanol: $0.1 \%$ acetic acid aqueous solution $(90: 10, v / v)$. The total runtime was 4.0 minutes. Mass spectrometer conditions were optimized and applied as the following: solvent gas temperature (nitrogen), $450^{\circ} \mathrm{C}$; capillary voltage, $3 \mathrm{KV}$; an ion source temperature, $110^{\circ} \mathrm{C}$; desolvation gas flow, $650 \mathrm{~L} /$ hour; cone gas flow, $300 \mathrm{~L} /$ hour. Data were analyzed using MassLynx version 4.1 data software.

\section{Preparation of Calibration Standards and Quality Control Samples}

Stock solutions of the standards, Alisol G ( $1 \mathrm{mg} / \mathrm{mL}$ in acetonitrile), were gradually diluted with acetonitrile to afford concentrations of $1,2.5,5,10,25,50,100$, and $250 \mu \mathrm{g} / \mathrm{mL}$. Quality control (QC) samples were diluted by stock solutions at the concentrations of $2,10,100$, and $250 \mu \mathrm{g} / \mathrm{mL}$. Rimonabant $(50 \mu \mathrm{g} / \mathrm{mL}$ in acetonitrile) was diluted to $0.5 \mu \mathrm{g} / \mathrm{mL}$ and used as an internal standard (I.S.). All working solutions were stored at $4^{\circ} \mathrm{C}$.

\section{Sample Pretreatment}

After thawing to r.t., rat tissue $(100 \mathrm{mg})$ was placed in a tissue homogenizer tube with $190 \mu \mathrm{L}$ acetonitrile, $200 \mu \mathrm{L}$ water, and homogenate bead (2-3 beads, diameters: $2 \mathrm{~mm}$ ) being added. The mixture was homogenized $(5,000 \mathrm{rpm}$ for $30 \mathrm{sec}-$ onds twice followed by $120,000 \mathrm{rpm}$ for 5 minutes). The supernatant $(200 \mu \mathrm{L})$ was vortexed in $1.4 \mathrm{~mL}$ tert-butyl methyl ether for 5 minutes, and centrifuged at $12,000 \mathrm{rpm}$ for 5 minutes. The supernatant $(1 \mathrm{~mL})$ in an $2 \mathrm{~mL}$ Eppendorf tube was solvent-dried under air at r.t.. The residue dissolved in $200 \mu \mathrm{L}$ of acetonitrile was used for UHPLC-MS/MS analysis with $2 \mu \mathrm{L}$ of the sample being used per injection.

\section{Methodology Validation}

The UHPLC-MS/MS bioanalytical method was developed and confirmed according to the accepted ChP Guidance 2015 for Industry with respect to selectivity, residue, linearity, lower limit of detection, quantification, precision and accuracy, extraction recovery, matrix effects, as well as method stability.

\section{Specificity and Residue}

The specificity of the method was determined based on the lack of endogenous substances' potential interfering peaks within the range of the retention time of Alisol G and I.S.. Blank sample was used to measure residue content after the injection of a sample with high concentration. The residue concentration in the blank sample should not exceed $20 \%$ of the quantitative lower limit and should also be controlled below $5 \%$ of the I.S.. 


\section{Linearity, Lower Limit of Detection, and Quantification}

Calibration curve plots of the Alisol G to I.S. peak-area ratio $(y$-axis) against concentration ( $x$-axis) were constructed using $1 / x$-weighed least-squares linear regression. Statistical analysis (linear regression and measurements of correlation coefficient, $r$ ) were calculated. The lower limit of quantification (LLOQ) of Alisol G was determined according to the response value of a signal-to-noise ratio of 10:1. The relative standard deviation (RSD) value of LLOQ should be within $20 \%$, and other QC concentrations should be within $15 \%$.

\section{Precision and Accuracy}

The intra- and interday precision and accuracy of Alisol G were assessed by analyzing QC samples at four concentrations (LLOQ QC low [QCL], QC middle [QCM], and QC high $[\mathrm{QCH}])$. The experiment was performed on 1 day and on 3 consecutive days, and each experiment had six duplicates. Precision and accuracy were defined as RSD and relative error, respectively.

\section{Extraction Recovery and Matrix Effects}

QC samples of Alisol G were added into blank liver tissue at four concentrations (QCL, QCM, QCH, LLOQ), and each experiment was repeated five times. The extraction recovery of Alisol $G$ was assessed by measuring the ratio of the average peak area to that calculated from the QC concentration without extraction. The matrix effect was determined by calculating the standard peak ratios, which were measured by comparing Alisol G/I.S. (dissolved in blank matrix extract) with those dissolved with mobile phase at different concentrations (LLOQ, QCL, QCM, and QCH). The RSD of the two effects mentioned above should be below $15 \%$.

\section{Stability}

The stability tests were designed to cover the expected conditions that real samples may experience. QC samples at three concentrations $(0.2 \mu \mathrm{g} / \mathrm{g}$ for QCL, $25 \mu \mathrm{g} / \mathrm{g}$ for $\mathrm{QCH}$, and $0.5 \mu \mathrm{g} / \mathrm{g}$ for I.S., respectively) were used. In terms of stability (for 6 hours at r.t.), postpreparative stability $\left(4^{\circ} \mathrm{C}\right.$ for 48 hours), freeze-thaw stability after three cycles $\left(-20^{\circ} \mathrm{C}\right.$ to $\mathrm{r}$. t. as one cycle), and long-term stability $\left(-20^{\circ} \mathrm{C}\right.$ for 98 days) were tested. All results were tested by using freshly prepared calibrators as a reference.

\section{Tissue Distribution Study}

Alisol G was mixed with $0.5 \%$ CMC-Na $(100 \mathrm{~mL})$ to make a suspension of $7.1 \mathrm{mg} / \mathrm{mL}$. Gavage was administered with a volume of approximately $1 \mathrm{~mL} / 100 \mathrm{~g}$ body weight. Twentyfive male SD rats were divided into five groups at random (five animals each group). Tissue distribution of Alisol G was conducted at $0,0.5,1.0,2.0,6.0$, and 10.0 hours, respectively. After being taken eye blood and being anesthetized with $20 \%$ urethane, the rats was subjected to chest dissections with heparin saline perfusion $(80 \mathrm{mg} / 500 \mathrm{~mL}$ of normal saline) flowing into the left ventricle and out of the right atrium. Different tissues (heart, liver, spleen, lung, kidney, brain, intestine and intestinal mucosa, adipose and muscle tissues) were collected and rinsed with physiological saline solution. The tissues were stored at $-80^{\circ} \mathrm{C}$ until analysis.

\section{Results and Discussion}

\section{Optimization of UHPLC-MS/MS Conditions}

To optimize MS/MS parameters, the feasibility of electrospray in both positive and negative ion modes was investigated. Alisol G and I.S. were found to show a higher response in the positive-ion mode. MRM was used to select the precursor ion and product ion (-Fig. 1). A precursor ion and two MRM transitions have been established for Alisol G. The parameters, such as cone voltage and collision energy, were optimized to acquire a higher sensitivity, which are shown in - Table 1. The quasi-molecular ion peak $m / z 455.16$ $\left[\mathrm{M}+\mathrm{H}-\mathrm{H}_{2} \mathrm{O}\right]^{+}$was generated by ionization in the full scanning mode of ESI.

\section{Methodology Validation}

After exposure the liver to different concentrations of Alisol $\mathrm{G}$ and I.S., typical MRM chromatograms of Alisol G and I.S. (rimonabant) in liver were measured. Alisol G and I.S. were eluted at retention times of 2.55 and 2.35 minutes, respectively (-Fig. 2). Under the validated UHPLC-MS/MS conditions, no interference peaks were observed at the retention times of Alisol G and I.S. This result revealed that biosamples could be accurately quantified with this method.

For the linear regression model of Alisol G established in the intestine and liver, the linear range was 0.5 to $25 \mu \mathrm{g} / \mathrm{g}$, and the LLOQ was $0.5 \mu \mathrm{g} / \mathrm{g}$. For that in other tissues, the linear range was 0.1 to $10 \mu \mathrm{g} / \mathrm{g}$, and the LLOQ was $0.1 \mu \mathrm{g} / \mathrm{g}$. All the linear regression models demonstrated a good correlation with $\gamma^{2}>0.99$ (-Table 2).

In general, a well-validated method is suitable for analysis of most tissue samples, ${ }^{7}$ liver tissue is more representative in the tissue due to its complex enzyme content that selected as the typical tissue for matrix effect, recovery, and long-term stability. ${ }^{8}$ The intra- and interday precision and accuracy tests of Alisol G were done by testing the QC sample at three concentrations in different tissues. - Table 3 indicates that this method has good repeatability and high accuracy for the determination of Alisol $G$ in rat tissues. The results of matrix effects and extraction recovery of Alisol G (-Table 4) revealed that there was no obvious matrix effect for the analyte; the extraction recoveries for Alisol $G$ were more than $78.5 \%$, which demonstrated that the selected method of extraction cannot inference the analyze. The stability results (-Table 5) demonstrated that Alisol G was stable in four storage conditions.

\section{Pharmacokinetic Study}

\section{Tissue Distribution Study of Alisol G}

DAS 2.1.1 pharmacokinetic software was used to process rat tissue concentration-time data. - Table 6 demonstrates the $C_{\max }$ tissue $/ C_{\max }$ brain and the area under the curve (AUC) tissue/AUC brain of Alisol G in various tissues. Alisol $G$ was 

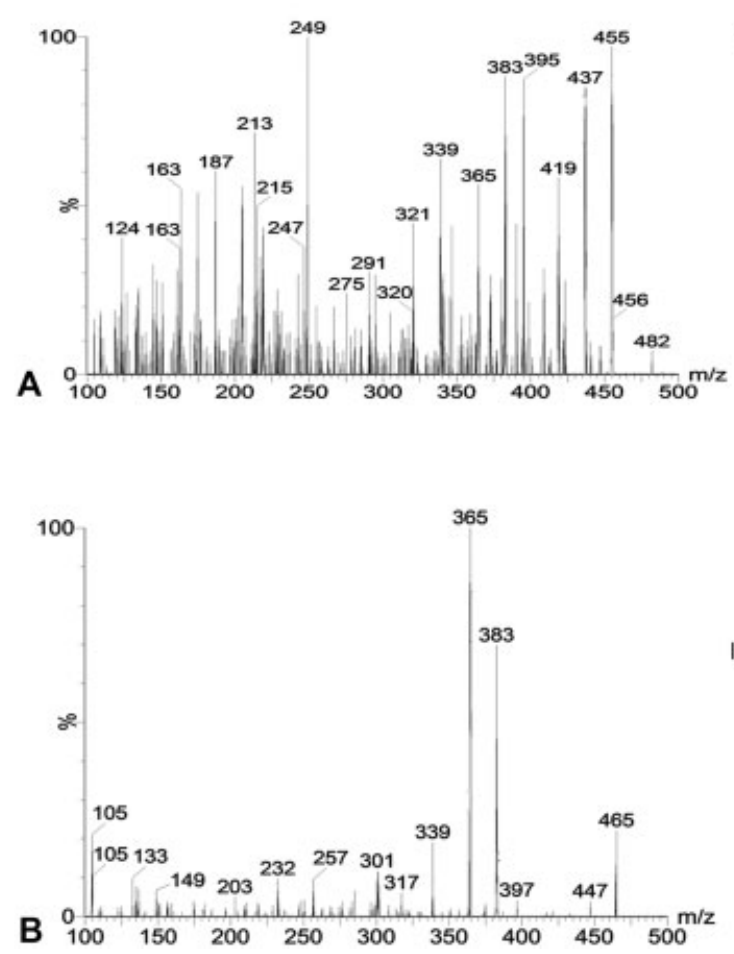

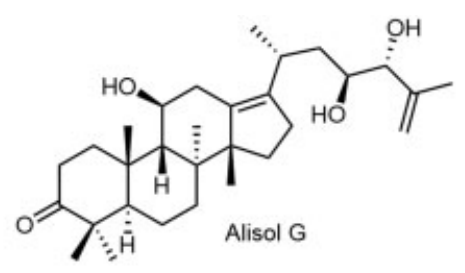

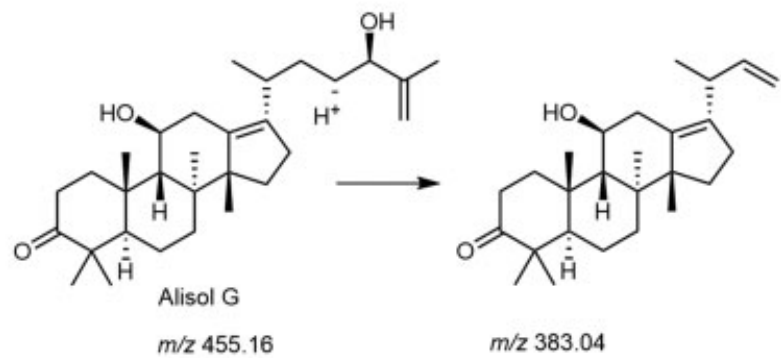

I.S.<smiles>[CH][NH+](C(=O)c1nn(-c2ccc(Cl)cc2Cl)c(-c2ccc(Cl)cc2)c1C)[NH+]1CCCCC1</smiles><smiles>[C-]#Cc1nn(-c2ccc(Cl)cc2Cl)c(-c2ccc(Cl)cc2)c1C</smiles>

Fig. 1 Chemical structures and full-scan product ion of precursor ions of (A) Alisol G and (B) internal standard (I.S.).

Table 1 Optimized mass spectrometry conditions for the determination of Alisol G and I.S.

\begin{tabular}{|l|l|l|l|l|}
\hline Analytes & $\begin{array}{l}\text { Precursor } \\
\text { ion }(\boldsymbol{m} / \mathbf{z})\end{array}$ & $\begin{array}{l}\text { Product } \\
\text { ion }(\boldsymbol{m} / \mathbf{z})\end{array}$ & $\begin{array}{l}\text { Cone } \\
\text { voltage } \\
(\mathrm{V})\end{array}$ & $\begin{array}{l}\text { Collision } \\
\text { energy } \\
(\mathrm{V})\end{array}$ \\
\hline Alisol G & 455.16 & 383.04 & 16 & 10 \\
\hline I.S. & 464.88 & 364.75 & 38 & 28 \\
\hline
\end{tabular}

Abbreviation: I.S., internal standard.

mainly distributed in intestinal mucosa tissue, and the concentration of Alisol $\mathrm{G}$ in this tissue was $177.8 \pm 67.7 \mu \mathrm{g} / \mathrm{g}$ after 1 hour of oral administration of Alisol $G$ in rats at a single dose of $71 \mathrm{mg} / \mathrm{kg}$. The tissue concentration of Alisol G in the jejunum, duodenum, and ileum were $51.51 \pm 18.1 \mu \mathrm{g} / \mathrm{g}$ (0.5 hour after oral administration of Alisol G), $38.85 \pm 12.3 \mu \mathrm{g} / \mathrm{g}$ ( 1 hour after oral administration of Alisol $\mathrm{G}$ ), and $26.14 \pm 12.2 \mu \mathrm{g} / \mathrm{g}$ ( 1 hour after oral administration of Alisol $G$ ), respectively. Liver tissue was found to be the secondary preference for Alisol G, reaching $9.03 \pm 5.27 \mu \mathrm{g} / \mathrm{g}$ ( 0.5 hour after oral administration of Alisol G). The exposure in the brain was much far lower than that in intestine and liver, only reaching $0.35 \pm 0.14 \mu \mathrm{g} / \mathrm{g}$ ( 2 hours after oral administration of Alisol G). Drug concentration-time curve in different tissues was showed in -Fig. 3.

As a CB1R antagonist, Alisol G was well absorbed in the intestine and liver but hardly absorbed in the brain, suggesting that Alisol $\mathrm{G}$ may be a peripheral CB1R antagonist.
Evidence shows that intestinal CB1R antagonism increases intestinal peristalsis, accelerates gastrointestinal emptying, and reduces fat accumulation, ${ }^{9}$ so Alisol G may represent a promising antiobesity drug.

According to the brain-gut axis theory, a large neuroendocrine network is formed between the central nervous system, enteric nervous system, and intestinal peptides. ${ }^{10}$ This explains that peripheral CB1R blockers can reduce body mass, promote fat cell metabolism, and muscle glucose uptake without relying on appetite suppression. ${ }^{11}$ Previous studies have found that fatty acid amide hydrolase (FAAH) is abundantly expressed in the colon; the distribution of FAAH in the intermuscular plexus corresponds to the CB1R. ${ }^{12}$ Bowel movement can be inhibited by $\mathrm{N}$-arachidonoyl serotonin (AA-5-HT) and FAAH inhibitor of palmitoylisopropylamide, as well as by the FAAH substrates palmitoylethanolamide, oleamide, and oleoylethanolamide. ${ }^{13}$ Wei et al report that a CB1R antagonist promotes oxidative catabolism of lipids in fat and liver tissues, inhibits endogenous lipid production, increases mitochondrial biosynthesis, promotes energy metabolism, and improves secretory metabolism of fat tissues. ${ }^{14}$ Thus, the specific mechanism underlying the antiobesity effects of Alisol $G$ was further studied in our laboratory; unfortunately, data are not available at present.

\section{BBB Permeability}

The plasma $C_{\max }(312.64 \mathrm{ng} / \mathrm{mL})$ of rats after oral administration was tested in our preliminary research, ${ }^{1}$ and the concentration of Alisol G in CSF is lower than LLOQ $(4 \mathrm{ng} / \mathrm{mL})$, suggesting that 


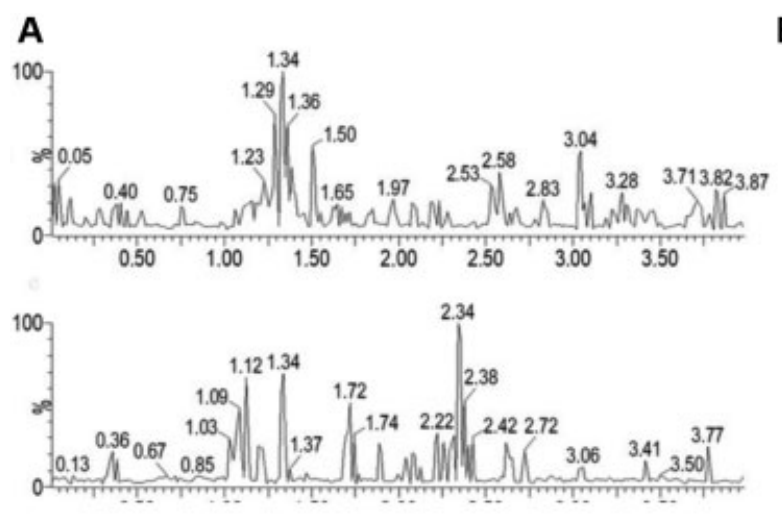

B
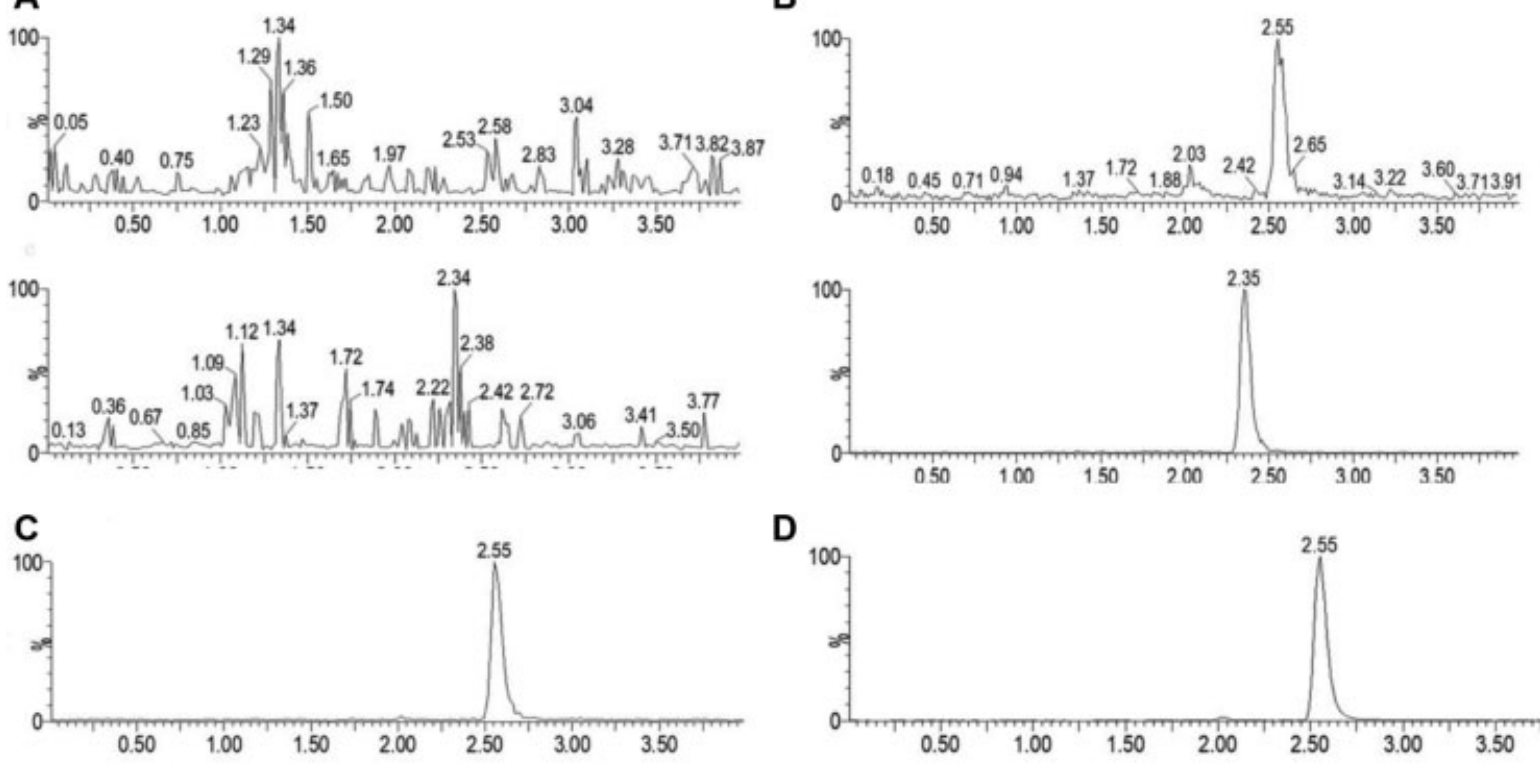

D
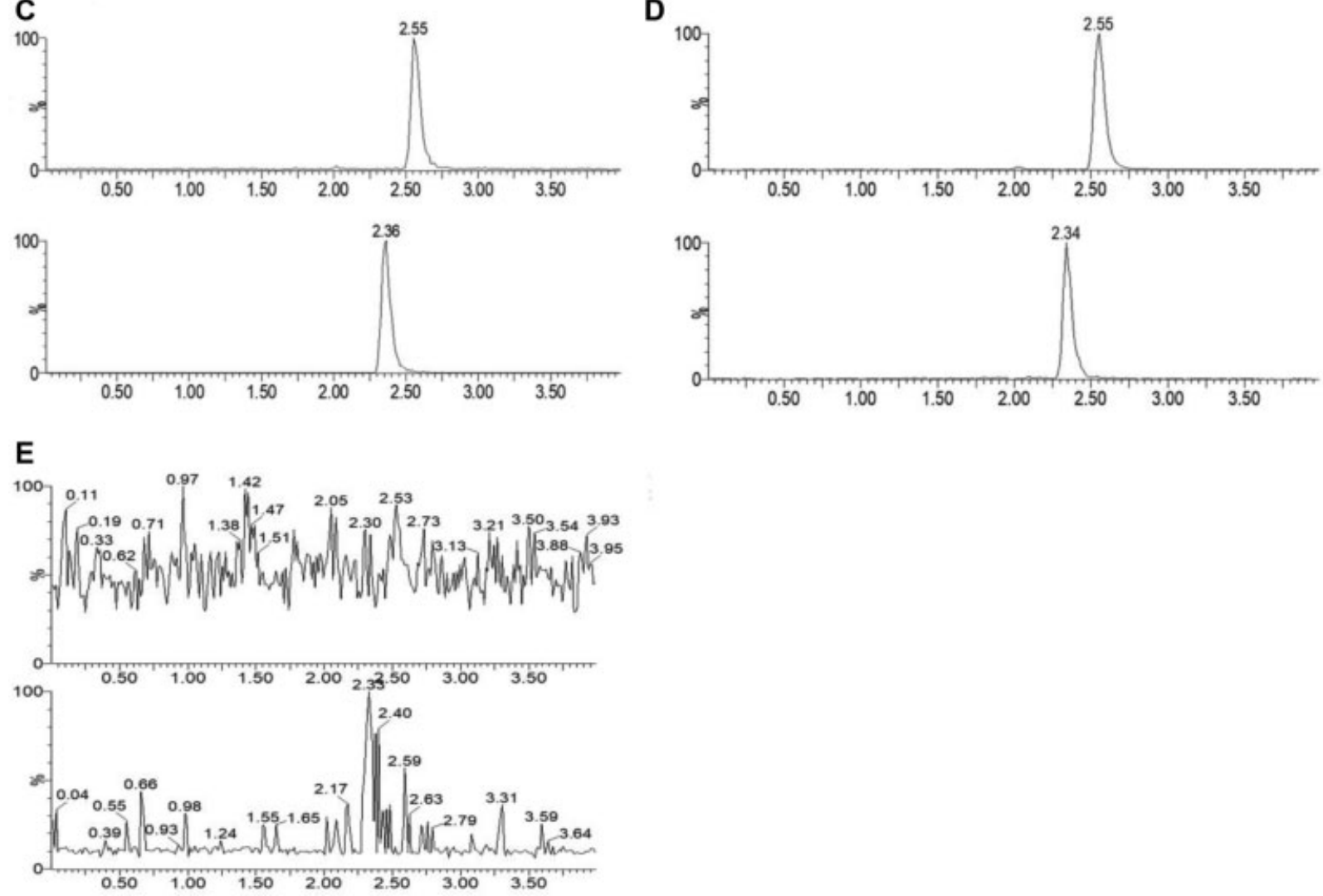

Fig. 2 Representative MRM chromatograms in (A) blank live tissue; (B) blank liver spiked with Alisol G LLOQ $(0.1 \mu \mathrm{g} / \mathrm{g})$ and I.S. (0.5 $\mu \mathrm{g} / \mathrm{g}) ;(C)$ blank liver spiked with Alisol G QC-L $(0.2 \mu \mathrm{g} / \mathrm{g})$ and I.S. $(0.5 \mu \mathrm{g} / \mathrm{g})$; (D) live tissue after 1 hour of administration of Alisol G in rat; and (E) live tissue with residue solvent. I.S., internal standard; LLOQ, lower limit of quantification; MRM, multiple reaction monitoring.

Alisol G can hardly cross the BBB. DAS 2.1.1 pharmacokinetic software was used to evaluate the rat pharmacokinetic parameters. The BBB permeability coefficient $(P)$ is calculated by the following Eq. $1 .{ }^{15}$ Where $t$ was corrected time of the sample, CPL drug concentration in plasma, CCSF drug concentration in CSF. The results are shown in - Tables $\mathbf{7}$ and $\mathbf{8}$.

$$
P=-\frac{1}{\mathrm{t}} \times \ln \left(\frac{C_{\mathrm{P} 1}-C_{\mathrm{CSF}}}{C_{\mathrm{P} 1}}\right) \text { (Eq. 1) }
$$

According to the free drug concentration hypothesis, ${ }^{16}$ the effective concentration of the drug in the brain is the free concentration of drug in the interstitial fluid of the brain, the CSF-brain barrier is the most incomplete, and the free drug concentration in the interstitial fluid of the brain tissue is close to the free drug concentration in the $\mathrm{CSF}^{6}$ Compared with $\mathrm{BBB}$, the capillary endothelial cells of the choroid plexus have window holes and have certain permeability in BCSFB. ${ }^{17}$ In clinical studies, CSF (instead of interstitial fluid) is preferred to monitor brain drug exposure. In our earlier studies, the CSF drug concentration and the measurement of BBB permeability also demonstrated that the drug rarely played a role in the brain, ${ }^{1}$ further indicating that Alisol $G$ is a peripheral CB1R antagonist and is not easy to pass the BBB. The concentration of Alisol $G$ in CSF is lower than LLOQ $^{1}$ and was only $0.35 \mu \mathrm{g} / \mathrm{g}$ in the brain after 2 hours of administration (-Fig. 3 ). There is a CSF-brain barrier to separate the brain and CSF, which composed of choroid plexus and arachnoid endothelial cell. Once the substance gets from the blood to CSF, it can 
A
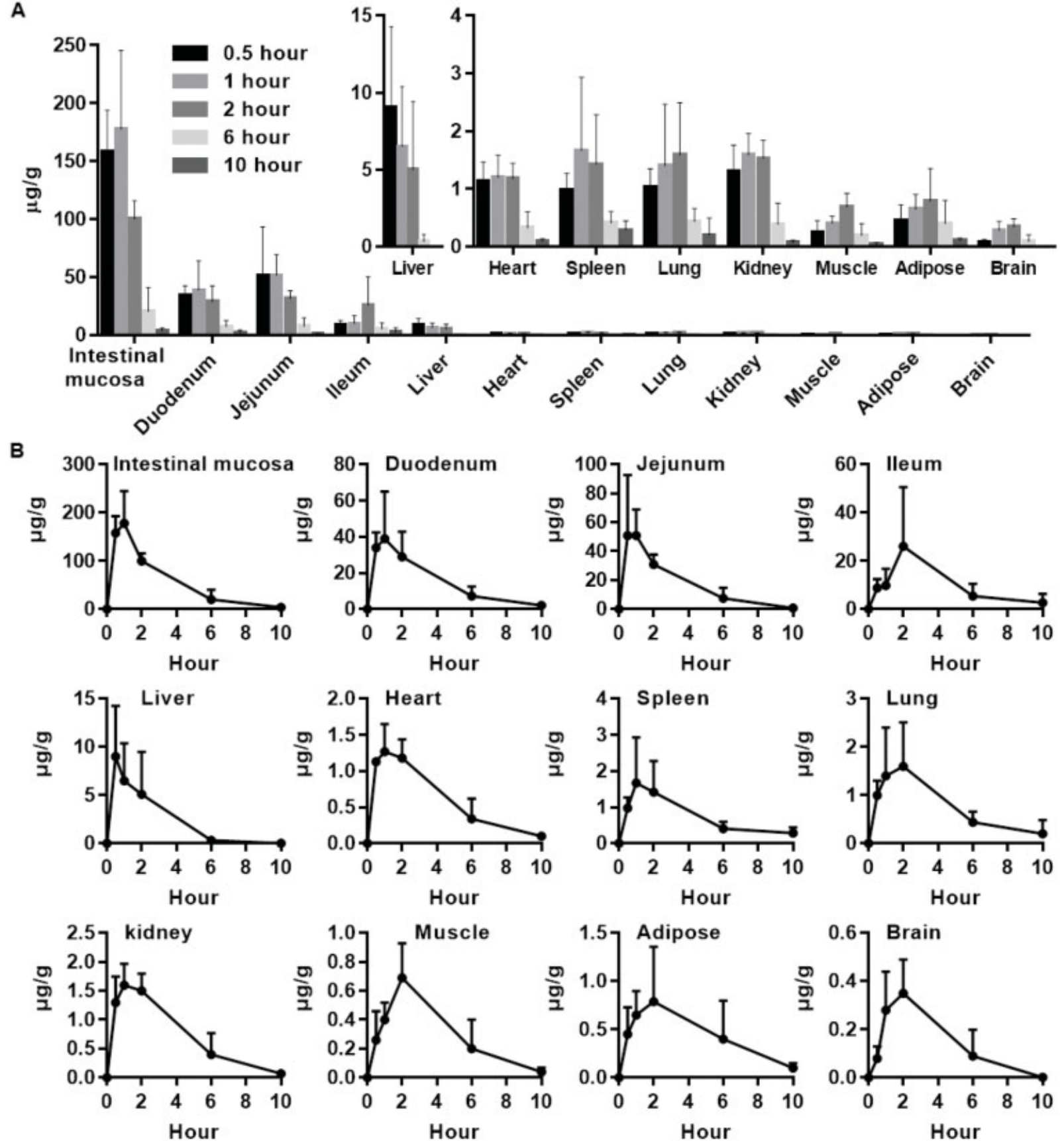

Fig. 3 Concentration of Alisol $G$ in various tissues at different times. (A) Concentration-time profiles and (B) distribution decline trend of Alisol G in every tissues. Each experiment was repeated at least five times.

diffuse freely into the brain. ${ }^{18}$ Based on the concentration of the Alisol G in CSF, our data suggested that the side effects of Alisol G on the central nervous system may be minimal or nonexistent.

\section{Conclusion}

A simple, rapid, and sensitive UPLC-MS/MS method was created and used for determining Alisol G concentration in rats' different tissues. To our knowledge, this is the first study to report the tissue distribution of Alisol G in rats. In this article, we suggested that Alisol G could be easily taken up by the intestine and livers but hardly by the brain, revealing that Alisol $G$ may be a peripheral CB1R antagonist. Furthermore, through calculating the $B B B$ permeability of this drug, we suggested that Alisol $G$ is difficult to cross the BBB and enter the brain tissue. Alisol $G$ does not function as a central CB1R antagonist in the brain, and thus may be high in safety for further obesity treatment. 
Table 2 Regression equation, linear range, and LLOQ of Alisol G in rat tissue

\begin{tabular}{|l|l|l|l|l|}
\hline Sample & Linearity range $(\mu \mathrm{g} / \mathrm{g})$ & Regression equation & $V^{2}$ & LLOQ $(\mu \mathrm{g} / \mathrm{g})$ \\
\hline Intestinal mucosa & $0.5-25$ & $Y=0.063986 X+17.7902$ & 0.9934 & 0.5 \\
\hline Duodenum & $0.5-25$ & $Y=0.022629 X+3.79483$ & 0.9945 & 0.5 \\
\hline Jejunum & $0.5-25$ & $Y=0.022629 X+3.79483$ & 0.9945 & 0.5 \\
\hline lleum & $0.5-25$ & $Y=0.022629 X+3.79483$ & 0.9945 & 0.5 \\
\hline Liver & $0.5-25$ & $Y=0.076049 X+15.0495$ & 0.9925 & 0.5 \\
\hline Heart & $0.1-10$ & $Y=0.060217 X+1.51822$ & 0.9960 & 0.1 \\
\hline Spleen & $0.1-10$ & $Y=0.080804 X+1.79795$ & 0.9913 & 0.1 \\
\hline Lung & $0.1-10$ & $Y=0.076802 X+3.09707$ & 0.9950 & 0.1 \\
\hline Kidney & $0.1-10$ & $Y=0.081794 X+5.53657$ & 0.9923 & 0.1 \\
\hline Adipose & $0.1-10$ & $Y=0.299092 X+0.62788$ & 0.9953 & 0.1 \\
\hline Muscle & $0.1-10$ & $Y=0.190466 X+10.1330$ & 0.9970 & 0.1 \\
\hline Brain & $0.1-10$ & $Y=0.067319 X+6.26916$ & 0.9944 & 0.1 \\
\hline
\end{tabular}

Abbreviation: LLOQ, lower limit of quantification.

Table 3 Precision and accuracy of Alisol G in rat different tissue homogenates $(n=6)$

\begin{tabular}{|c|c|c|c|c|c|c|c|}
\hline \multirow[t]{2}{*}{ Tissue } & \multirow{2}{*}{$\begin{array}{l}\text { Linearity } \\
\text { range } \\
(\mu g / g)\end{array}$} & \multirow[t]{2}{*}{ Analytes } & \multirow{2}{*}{$\begin{array}{l}\text { Spiked } \\
\text { concentration } \\
(\mu g / g)\end{array}$} & \multicolumn{2}{|l|}{ Intraday } & \multicolumn{2}{|l|}{ Interday } \\
\hline & & & & $\begin{array}{l}\text { Precision } \\
\text { (RSD, \%) }\end{array}$ & $\begin{array}{l}\text { Accuracy } \\
\text { (mean\%) }\end{array}$ & $\begin{array}{l}\text { Precision } \\
\text { (RSD, \%) }\end{array}$ & $\begin{array}{l}\text { Accuracy } \\
\text { (mean\%) }\end{array}$ \\
\hline \multirow[t]{4}{*}{ Liver } & \multirow[t]{4}{*}{$0.1-10$} & \multirow[t]{3}{*}{ Alisol G } & 0.2 & 8.12 & -4.80 & 8.46 & -5.55 \\
\hline & & & 1 & 5.23 & 0.23 & 4.46 & 0.04 \\
\hline & & & 10 & 2.53 & -2.90 & 5.90 & -5.28 \\
\hline & & I.S. & 0.5 & 7.96 & -1.10 & 6.86 & -0.66 \\
\hline \multirow[t]{4}{*}{ Intestinal } & \multirow[t]{4}{*}{$0.5-25$} & \multirow[t]{3}{*}{ Alisol G } & 1 & 5.65 & 3.60 & 8.17 & 3.29 \\
\hline & & & 10 & 4.54 & 3.00 & 4.85 & 4.44 \\
\hline & & & 25 & 2.07 & 0.94 & 5.86 & 2.30 \\
\hline & & I.S. & 0.5 & 6.70 & -4.31 & 4.90 & -0.67 \\
\hline \multirow[t]{4}{*}{ Heart } & \multirow[t]{4}{*}{$0.1-10$} & \multirow[t]{3}{*}{ Alisol G } & 0.2 & 11.53 & 1.46 & 14.90 & 4.90 \\
\hline & & & 1 & 8.65 & -5.56 & 5.19 & -9.70 \\
\hline & & & 10 & 3.57 & -13.90 & 2.06 & -5.74 \\
\hline & & I.S. & 0.5 & 2.23 & 4.47 & 2.06 & 1.03 \\
\hline \multirow[t]{4}{*}{ Spleen } & \multirow[t]{4}{*}{$0.1-10$} & \multirow[t]{3}{*}{ Alisol G } & 0.2 & 5.59 & -3.57 & 5.22 & -9.47 \\
\hline & & & 1 & 4.56 & -2.98 & 6.36 & -7.70 \\
\hline & & & 10 & 2.29 & -12.21 & 2.65 & -14.7 \\
\hline & & I.S. & 0.5 & 6.84 & 1.96 & 3.44 & 11.90 \\
\hline \multirow[t]{4}{*}{ Lung } & \multirow[t]{4}{*}{$0.1-10$} & \multirow[t]{3}{*}{ Alisol G } & 0.2 & 9.05 & 3.32 & 11.6 & -7.75 \\
\hline & & & 1 & 2.26 & -1.65 & 6.83 & -2.90 \\
\hline & & & 10 & 1.88 & -10.62 & 7.81 & 1.05 \\
\hline & & I.S. & 0.5 & 4.45 & 1.60 & 9.85 & -4.47 \\
\hline \multirow[t]{4}{*}{ Kidney } & \multirow[t]{4}{*}{$0.1-10$} & \multirow[t]{3}{*}{ Alisol G } & 0.2 & 10.08 & -9.43 & 6.11 & -12.70 \\
\hline & & & 1 & 7.03 & 7.32 & 3.48 & -1.67 \\
\hline & & & 10 & 2.05 & 5.42 & 4.62 & 6.87 \\
\hline & & I.S. & 0.5 & 4.25 & -4.23 & 7.72 & -6.90 \\
\hline
\end{tabular}


Table 3 (Continued)

\begin{tabular}{|c|c|c|c|c|c|c|c|}
\hline \multirow[t]{2}{*}{ Tissue } & \multirow{2}{*}{$\begin{array}{l}\text { Linearity } \\
\text { range } \\
(\mu g / g)\end{array}$} & \multirow[t]{2}{*}{ Analytes } & \multirow{2}{*}{$\begin{array}{l}\text { Spiked } \\
\text { concentration } \\
(\mu g / g)\end{array}$} & \multicolumn{2}{|l|}{ Intraday } & \multicolumn{2}{|l|}{ Interday } \\
\hline & & & & $\begin{array}{l}\text { Precision } \\
\text { (RSD, \%) }\end{array}$ & $\begin{array}{l}\text { Accuracy } \\
\text { (mean\%) }\end{array}$ & $\begin{array}{l}\text { Precision } \\
\text { (RSD, \%) }\end{array}$ & $\begin{array}{l}\text { Accuracy } \\
\text { (mean\%) }\end{array}$ \\
\hline \multirow[t]{4}{*}{ Adipose } & \multirow[t]{4}{*}{$0.1-10$} & \multirow[t]{3}{*}{ Alisol G } & 0.2 & 13.44 & -11.71 & 11.50 & 2.54 \\
\hline & & & 1 & 12.20 & 3.54 & 13.97 & 4.01 \\
\hline & & & 10 & 9.19 & 6.37 & 10.28 & -8.07 \\
\hline & & I.S. & 0.5 & 6.84 & 2.87 & 1.77 & -8.66 \\
\hline \multirow[t]{4}{*}{ Muscle } & \multirow[t]{4}{*}{$0.1-10$} & \multirow[t]{3}{*}{ Alisol G } & 0.2 & 9.42 & 4.30 & 10.29 & 1.13 \\
\hline & & & 1 & 10.21 & -2.45 & 10.16 & 0.70 \\
\hline & & & 10 & 7.34 & 6.55 & 6.69 & 5.63 \\
\hline & & I.S. & 0.5 & 1.02 & 2.80 & 4.78 & -7.33 \\
\hline \multirow[t]{4}{*}{ Brain } & \multirow[t]{4}{*}{$0.1-10$} & \multirow[t]{3}{*}{ Alisol G } & 0.2 & 5.11 & 4.59 & 5.86 & 9.31 \\
\hline & & & 1 & 3.64 & -6.73 & 4.64 & -11.55 \\
\hline & & & 10 & 4.56 & -7.38 & 0.49 & -7.00 \\
\hline & & I.S. & 0.5 & 4.67 & 7.67 & 3.53 & 5.42 \\
\hline
\end{tabular}

Abbreviations: I.S., internal standard; RSD, relative standard deviation.

Table 4 Matrix effect and extraction recovery of Alisol G in rat liver homogenate $(n=6)$

\begin{tabular}{|l|l|l|l|l|l|}
\hline \multirow{2}{*}{ Analytes } & Spiked concentration $\mathbf{( n g} / \mathbf{g})$ & \multicolumn{2}{l|}{ Matrix effect } & \multicolumn{2}{l|}{ Extraction recovery } \\
\cline { 3 - 7 } & & Mean \pm SD (\%) & RSD (\%) & Mean \pm SD (\%) & RSD (\%) \\
\hline \multirow{3}{*}{ Alisol G } & 0.1 & $104.57 \pm 6.99 \%$ & 6.68 & $73.40 \pm 8.31$ & 11.32 \\
\cline { 2 - 7 } & 0.2 & $99.88 \pm 6.7 \%$ & 6.70 & $79.9 \pm 4.02$ & 5.03 \\
\cline { 2 - 7 } & 10 & $101.57 \pm 1.13 \%$ & 1.12 & $71.23 \pm 3.51$ & 4.93 \\
\cline { 2 - 7 } & 25 & $97.63 \pm 10.1 \%$ & 10.3 & $78.51 \pm 2.07$ & 2.64 \\
\hline I.S. & 0.5 & $95.06 \pm 8.64 \%$ & 9.1 & $86.5 \pm 5.7$ & 6.57 \\
\hline
\end{tabular}

Abbreviations: I.S., internal standard; RSD, relative standard deviation; SD, standard deviation.

Table 5 Stability test of Alisol G in rat liver homogenate $(n=6)$

\begin{tabular}{|c|c|c|c|c|c|c|c|c|c|}
\hline \multirow[t]{2}{*}{ Analytes } & \multirow[t]{2}{*}{ Spiked concentration $(\mu g / g)$} & \multicolumn{2}{|c|}{$\begin{array}{l}\text { Short-term (at } \\
\text { room tempera- } \\
\text { ture for } 6 \mathrm{~h} \text { ) }\end{array}$} & \multicolumn{2}{|c|}{$\begin{array}{l}\text { Three freeze- } \\
\text { thaw cycles }\end{array}$} & \multicolumn{2}{|c|}{$\begin{array}{l}\text { Autosampler } \\
\text { (at } 4^{\circ} \mathrm{C} \text { for } 48 \mathrm{~h} \text { ) }\end{array}$} & \multicolumn{2}{|c|}{$\begin{array}{l}\text { Long term (at } \\
-20^{\circ} \mathrm{C} \text { for } 98 \mathrm{~d} \text { ) }\end{array}$} \\
\hline & & RE (\%) & RSD\% & RE (\%) & RSD\% & RE (\%) & RSD\% & RE (\%) & RSD\% \\
\hline \multirow[t]{2}{*}{ Alisol G } & 0.2 & -5.00 & 6.99 & -8.20 & 12.76 & -6.60 & 5.81 & -8.24 & 7.74 \\
\hline & 25 & 3.80 & 3.16 & 0.70 & 3.04 & 13.4 & 1.13 & 5.30 & 3.64 \\
\hline I.S. & 0.5 & -3.20 & 5.82 & 4.00 & 5.61 & 14.00 & 1.70 & -3.6 & 7.84 \\
\hline
\end{tabular}

Abbreviation: I.S., internal standard. 
Table $6 C_{\max }$ and AUC concentration ratio of tissue to brain in rats after oral administration

\begin{tabular}{|l|l|l|}
\hline Tissues & $\begin{array}{l}C_{\max } \text { tissue/ } \\
C_{\max } \text { brain }\end{array}$ & $\begin{array}{l}\text { AUC tissue/ } \\
\text { AUC brain }\end{array}$ \\
\hline Intestinal mucosa & 514.69 & 372.60 \\
\hline Duodenum & 112.45 & 102.25 \\
\hline Jejunum & 149.10 & 117.92 \\
\hline Ileum & 75.67 & 70.45 \\
\hline Liver & 26.14 & 15.81 \\
\hline Heart & 3.68 & 4.07 \\
\hline Spleen & 4.83 & 5.09 \\
\hline Lung & 4.61 & 5.19 \\
\hline Kidney & 4.62 & 5.00 \\
\hline Adipose & 1.99 & 2.04 \\
\hline Muscle & 2.29 & 3.04 \\
\hline
\end{tabular}

Abbreviation: AUC, area under the curve.

Table 7 Plasma pharmacokinetic parameters of Alisol G in rats after oral administration ${ }^{1}(n=6)$

\begin{tabular}{|l|l|l|}
\hline Parameter & Unit & Result \\
\hline $\mathrm{AUC}_{(0-\mathrm{t})}$ & $\mu \mathrm{g} / \mathrm{L} \times \mathrm{h}$ & $3,120.767 \pm 316.41$ \\
\hline $\mathrm{AUC}_{(0-\infty)}$ & $\mu \mathrm{g} / \mathrm{L} \times \mathrm{h}$ & $3,155.543 \pm 323.13$ \\
\hline $\mathrm{MRT}_{(0-\mathrm{t})}$ & $\mathrm{h}$ & $4.326 \pm 0.57$ \\
\hline $\mathrm{MRT}_{(0-\infty)}$ & $\mathrm{h}$ & $4.431 \pm 0.60$ \\
\hline$t 1 / 2 z$ & $\mathrm{~h}$ & $1.336 \pm 0.19$ \\
\hline$T_{\max }$ & $\mathrm{h}$ & $4 \pm 1.98$ \\
\hline $\mathrm{CLz} / \mathrm{F}$ & $\mathrm{L} /(\mathrm{h} / \mathrm{kg})$ & $22.704 \pm 2.39$ \\
\hline $\mathrm{Vz} / \mathrm{F}$ & $\mathrm{L} / \mathrm{kg}$ & $43.947 \pm 8.56$ \\
\hline$C_{\max }$ & $\mu \mathrm{g} / \mathrm{L}$ & $633.55 \pm 108.09$ \\
\hline
\end{tabular}

Abbreviations: AUC, area under the curve; MRT, mean residence time.

Table 8 Blood-brain barrier permeability coefficient of Alisol G in rats after oral administration ${ }^{1}$

\begin{tabular}{|l|l|}
\hline Time (h) & CSF P $\left(\mathrm{min}^{-1}\right)$ \\
\hline 0.5 & 0.00072 \\
\hline 1 & 0.00022 \\
\hline 2 & 0.00013 \\
\hline 6 & 0.00007 \\
\hline 10 & 0.00008 \\
\hline
\end{tabular}

Abbreviation: CSF, cerebrospinal.

\section{Funding}

This work was supported by China State Institute of Pharmaceutical Industry, National Pharmaceutical Engineering Research Center, Shanghai 201203, People's Republic of China.
Conflicts of Interests

The authors declare no conflicts of interests.

\section{References}

1 Zhao J, Xi JQ Zhang BB, Song DZ, Cheng ZH. Pharmacokinetics and blood-brain barrier permeability of CB1R partial antagonist alisol $\mathrm{g}$ in rats [in Chinese]. Chinese J Pharm 2020;51(01):95-102

$2 \mathrm{Wu}$ YK, Yeh CF, Ly TW, Hung MS. A new perspective of cannabinoid 1 receptor antagonists: approaches toward peripheral CB1R blockers without crossing the blood-brain barrier. Curr Top Med Chem 2011;11(12):1421-1429

3 Han JH, Shin H, Park JY, et al. A novel peripheral cannabinoid 1 receptor antagonist, AJ5012, improves metabolic outcomes and suppresses adipose tissue inflammation in obese mice. FASEB J 2019;33(03):4314-4326

4 Moreira FA, Crippa JAS. The psychiatric side-effects of rimonabant. Br J Psychiatry 2009;31(02):145-153

5 Christensen R, Kristensen PK, Bartels EM, Bliddal H, Astrup A. Efficacy and safety of the weight-loss drug rimonabant: a meta-analysis of randomised trials. Lancet 2007;370 (9600):1706-1713

6 Lin JH. CSF as a surrogate for assessing CNS exposure: an industrial perspective. Curr Drug Metab 2008;9(01):46-59

7 Li WK, Zhang J, Xie LC. Handbook of LC-MS Bioanalysis: Best Practices, Experimental Protocols, and Regulations. 2nd ed. Peking: Science Press; 2017:335-345

8 Liu BX. Pharmacokinetics and Tissue Distribution Study of 3, 4', 5 Trimethoxy-trans-stilbene in Rats. Hebei: Hebei Medicine University; 2018

9 Shi D, Zhan X, Yu X, et al. Inhibiting CB1 receptors improves lipogenesis in an in vitro non-alcoholic fatty liver disease model. Lipids Health Dis 2014;13:173

10 Kang A, Hao H, Zheng X, et al. Peripheral anti-inflammatory effects explain the ginsenosides paradox between poor brain distribution and anti-depression efficacy. J Neuroinflammation 2011;8:100

11 Nogueiras R, Veyrat-Durebex C, Suchanek PM, et al. Peripheral, but not central, CB1 antagonism provides food intake-independent metabolic benefits in diet-induced obese rats. Diabetes 2008;57(11):2977-2991

12 Qiao L, Chen CS, Zhang SC. Significance of expression of fatty acid amide hydrolase in normal colon wall. World Chin J Digestology 2009;17:2266-2271

13 Capasso R, Matias I, Lutz B, et al. Fatty acid amide hydrolase controls mouse intestinal motility in vivo. Gastroenterology 2005;129(03):941-951

14 Wei LW, Yuan Z, Zhao M, Han J, Gu C, Fu L. Effect of cannabinoid receptor 1 on lipid metabolism in diet- induced obese mice. Sichuan Dong Wu 2018;37(01):51-56

15 Liang QW. Biopharmaceutics and Pharmacodynamics. 3rd ed. Peking: Peoples Medical Publishing House; 2007:119

16 Dasgupta A. Usefulness of monitoring free (unbound) concentrations of therapeutic drugs in patient management. Clin Chim Acta 2007;377(1-2):1-13

17 Jing HM, Li GJ. Progress in structure, function and toxicological research of blood-cerebrospinal fluid barrier. Zhongguo Yaolixue Yu Dulixue Zazhi 2010;24:562-565

$18 \mathrm{Xu} \mathrm{W}$, Li X, Lin N, et al. Pharmacokinetics and tissue distribution of five major triterpenoids after oral administration of Rhizoma Alismatis extract to rats using ultra high-performance liquid chromatography-tandem mass spectrometry. J Pharm Biomed Anal 2017;146:314-323 